\title{
THE INFLUENCE OF GOOD CORPORATE GOVERNANCE AND CAPITAL STRUCTURE ON FIRM VALUE: THE MEDIATION ROLE OF FINANCIAL PERFORMANCE
}

\author{
Ridwan Nurazi \\ Faculty of Economic and Bussiness, University of Bengkulu, Indonesia \\ Email: ridwan.nurazi@unib.ac.id \\ Intan Zoraya \\ Faculty of Economic and Bussiness, University of Bengkulu, Indonesia \\ Email:izoraya@unib.ac.id \\ Akram Harmoni Wiardi \\ Faculty of Economic and Bussiness, University of Bengkulu, Indonesia \\ Email:akramharmoni83@unib.ac.id
}

Received: June 2020; Accepted: June 2020; Available online: July 2020

\begin{abstract}
The objective of this study is empirically identify the impacts of Good Corporate Governance and capital structure on firm value with financial performance as intervening variable. We operate quantitative approach within the scope of manufacturing company of metal, chemical, and plastic packaging sector which listed in Indonesia Stock Exchange during the 2017-2018 periods as the population. Samples are chosen by purposive sampling method inwhich the company must report the financial statement in a row, obtained 79 observations. The data analysis technique used is financial ratio analysis to determine the condition of the business financial ratios of the variables studied. Data were analyzed using multiple linear regression analysis. The result shows that corporate governance and capital structure influence the firm value, moreover the use of institutional ownership ratio and capital structure will increase the value of the firm. The result also shows that the impact of Corporate governance and capital structure on the company value are mediated by financial performance. It means that the value of the firm can increase if the company able became an effective monitoring tool.
\end{abstract}

Keywords : Good Corporate Governance; capital structure; financial performance and firm Value.

\begin{abstract}
Abstrak
Tujuan dari penelitian ini adalah untuk mengidentifikasi secara empiris dampak Good Corporate Governance dan struktur modal dari nilai perusahaan dengan kinerja keuangan sebagai variabel intervening. Penelitian adalah sejenis penelitian kuantitatif. Populasi dalam penelitian ini adalah perusahaan manufaktur sektor logam, kimia, dan kemasan plastik yang terdaftar di Bursa Efek Indonesia selama periode 2017-2018. Sampel dipilih dengan menggunakan porposive sampling dimana semua perusahaan harus melaporkan laporan keuangan secara berurutan, diperoleh 79 observasi. Teknik analisis data yang digunakan adalah analisis rasio keuangan untuk mengetahui kondisi rasio keuangan bisnis dari variabel yang diteliti. Data dianalisis menggunakan analisis regresi linier berganda. Hasil penelitian menunjukkan bahwa tata kelola perusahaan dan struktur modal mempengaruhi nilai
\end{abstract}


perusahaan, secara khusus rasio kepemilikan institusional dan struktur modal dapat meningkatkan nilai perusahaan. Hasil penelitian juga menunjukkan bahwa pengaruh tata kelola perusahaan dan struktur modal terhadap nilai perusahaan dimediasi oleh kinerja keuangan. Hal ini menunjukkan bahwa nilai perusahaan dapat meningkat secara signifikan apabila perusahaan dapat berperan sebagai alat monitoring yang efektif.

Kata kunci: Tata Kelola Perusahaan yang Baik; struktur modal; kinerja keuangan dan Nilai Perusahaan.

How to Cite: Nurazi, R., Zoraya, I., \& Winardi, A. H. (2020). The Influence of Good Corporate Governance and Capital Structure on Firm Value: The Mediation Role of Financial Performance. Media Ekonomi dan Manajemen, 35(2), $230-242$. doi: http://dx.doi.org/10.24856/mem.v35i2.1554.

\section{INTRODUCTION}

Company value reflect the value of assets owned by the company and the higher the value of the firms, the company will have a better image. Brigham and Houston (2011) define agency theory as a relationship in which managers are given power by shareholders. However, both of them are vulnerable to differences in interests that can cause agency problems.

According to the Forum for Corporate Governance in Indonesia (FCGI), corporate governance is a set of rules governing the relationship between holders, managers of companies, creditors, government, employees and other internal and external stakeholders relating to rights and obligations or in other words a system that controls a company. The purpose of Corporate Governance is to create added value for all interested parties (i.e, stakeholders). Susanti in Amanti (2012) states that Good Corporate Governance (i.e, GCG) can create added value because by implementing CGC, it is expected that the company will have good performance so as to create added value and increase the value of the company which can provide benefits for shareholders or company owner. In more detail, the term corporate governance can be used to explain the role and behavior of the board of directors, the board of commissioners, the management of the company, and shareholders.
The concept of GCG can properly minimize information asymmetry and conflicts of interest between principals and agents, encouraging agents to present actual information to the principal, especially if the information is related to agent performance measurements. The managers maybe use their decisions in financial reporting and in making transactions to overcome smooth financial statements both to give a good perspective for stakeholders about the financial performance of the company (Merchant and Rockness, 1994). According to Brigham and Houston (2011), capital structure is a proportion or comparison in determining the fulfillment of corporate spending needs, whether by using debt, equity, or by issuing shares. In a company, of course, to finance all activities is a company consideration because from an economic point of view capital structure is very influential in allocating funds both short and long term, of course the company has plans in the future, so that the opportunity in allocating funds will be optimal. Capital structure decisions include the selection of sources of funds both from their own capital and foreign capital in the form of debt, both of these funds are external funds that can affect the value of the company. In addition to profits, the negative impact can also be caused by debt that is too high is the risk of default due to high interest costs and principal debt that exceeds the benefits provided from the debt so that it can cause the value of the company to decline. Capital structure is 
needed to increase the value of the company because the determination of capital structure in the company's financing policy determines the profitability and position of the company (Effendi, 2017)

The company's financial performance is one of the factors seen by potential investors to determine stock investment (Kanter \& Siagian, 2017). For a company, maintaining and improving financial performance is one of the necessities for these shares to continue to exist and remain in demand by investors. In relation to performance, the company's financial statements are a reflection of the company's financial performance. Measurement of financial performance is one indicator used by investors to assess a company from the market price of these shares on the Indonesia Stock Exchange. The better the company's performance, the higher the returns that will be obtained by investors. Generally investors will look for companies that have the best performance and invest their capital in these companies.

Measurement of the company's financial performance with ROA shows the ability of capital invested in overall assets held to generate profits (Atidhira \& Yustina, 2017). The existence of assets is important to consider because the financing of expensive assets is expected to provide maximum results in upholding the company's operational activities. Operational activities that work optimally can have an impact on profits earned by the company because the company's operations run with the goals to be achieved by the company. Companies that have high corporate value can increase shareholder wealth, so shareholders can invest their capital in these companies. With the competition between companies that are competitive, it must be supported by the presentation of good financial statements. The financial statements made by the company can show the company's financial performance that can reflect the true state of the company. The mana- gement as a party directly involved in managing the company must have more adequate information compared to investors. Investors tend to receive information only from management through financial statements without knowing the true condition of the company.

The basic industry and chemicals companies (metal, chemical and plastic packaging sector) are technology-oriented companies so that these sector shares have good prospects in the future (Adinatan \& Fachrudin, 2013). They analyze any differences of systematic risk and unsystematic risk of cement subsector; ceramics, porcelain and glass subsector; metal and allied products subsector; chemicals subsector; plastics and packaging subsector; animal feed subsector; wood industries subsector and; pulp and paper subsector in Basic Industry and Chemicals' companies that were listed in the Indonesia Stock Exchange. The results of the first hypothesis shows that there were an average difference of systematic risk between cement subsector and those of ceramics, porcelain and glass subsector, metal and allied subsector, plastics and packaging subsector, and pulp and paper subsector. The results of the second hypothesis shows that there were no differences of unsystematic risk among all the subsectors in the Basic Industry and Chemicals' companies.

The differences of the research findings related to the influence of corporate governance and environmental performance to company's financial performance is necessity to do further research on this particular topic. Increasingly rapid economic development requires all companies to be more sensitive in reading situations and conditions both viewed from the internal and external sides of the company. The survival of a company depends on its corporate governance and capital structure would maximizes the company's market price of share by increasing earnings per share of 
the ordinary shareholders. It also increases dividend receipt of the shareholders. Investment Opportunity: Capital structure increases the ability of the company to find new wealth-creating investment opportunities.

\section{LITERATURE REVIEW}

The implementation of Good Corporate Governance in Indonesia is still quite low in ASEAN countries (Garbo \& Wulandari, 2018). The result of a survey from the Asian Corporate Governance Association (ACGA) show Indonesia is the lowest rank after China and Korea. The Implementation of GCG is low because management's awareness of a value and practice in carrying out business activities is still limited to meeting regulations not because of teh need for the company. Corporate governance deals with institutional ownership.

In addition to institutional ownership is also related to capital structure. Capital structure is a picture of the form of corporate financial proportion, which is between owned capital sourced from longterm liabilities and shareholder's equity which is the source and financing of a company (Fahmi, 2013:184). Funding through debt will force managers to be more disciplined, because if the debt is not paid in accordance with what the creditor asks, the company will go bankrupt, in which case the manager will lose his job (Brigham and Houston 2010: 185). While according to MM theory states that the company having debt will have more value compared to companies without debt. This is because, an increase in the value of the company occurs because the payment of interest on debt is a tax deduction, therefore the operating profit received by investors will be greater, the next impact is because the profit received is greater, the value of the firm will also be large (Kamaludin, 2011: 312). So the higher the capital structure that comes from debt would influence the value of the company. The theory regarding capital structure is a theory that explains the company's debt and equity funding policies to maximize the value of the company, in accordance with the trade-off theory, if the Debt to Equity Ratio (i.e, DER) gets higher so the price of book value (i.e, PBV) will increase as long as the DER has not reached its optimal point (Husnan, 2004).

Healy and Wahlen (1999) conclude that some managers are motivated to raise profits before the initial public offering with the aim to influence the expectations of investors and / or potential investors about the company's future performance and increase the price of the initial public offering. Whereas contractual objectives, managers perform earnings management because they avoid violating debt agreements, or to increase compensation and provide information about managerial performance.

Institutional ownership is that some shares are held directly by individual investors but a large proportion is owned by financial institutions such as mutual funds, pension funds, and insurance companies (Brealey et al, 2007: 388). Institutional ownership has the ability to control management through an effective monitoring process so as to reduce earnings management. The existence of ownership by institutional investors will encourage increased oversight of more optimal management performance, because ownership of shares represents a source of power that can be used to support or vice versa on management performance (Kusumaningtyas, 2015).

The higher institutional ownership will have an influence on the financial reporting process, so that it can give a positive reaction to prospective investors in assessing the company. Institutional investors can also be effective owners because they have the resources and ability to monitor management decisions (Muryati and Suardhika, 2014). Institutional share 
ownership has a positive effect indicating that the control function of the owner is crucial in improving company performance. Theoretically, the higher institutional ownership, the stronger control over the company, the performance I value of the company will increase if the owner of the company can control management behavior to act in accordance with company goals (Widyati, 2013). The greater the institutional ownership, the more efficient the use of company assets and it is also expected to act as a prevention against waste by the management. The greater the ownership by financial institutions, the greater the sound power and drive to optimize corporate value (Suhartanti, 2015). So the higher the institutional ownership, the higher the value of the company.

\section{Hypotheses Development}

In addition to institutional ownership is also related to capital structure. Capital structure is an illustration of the form of corporate financial proportion, which is between owned capital sourced from longterm liabilities and shareholder's equity which is the source and financing of a company (Fahmi, 2013: 184). Funding composition includes debt short term, long term debt and own capital. The financial structure of a company often changes due to the investment the company will make. Therefore, the size of the investment to be made by the company will affect the composition of the company's funding. Funding through large debt will have a good effect on the company, because debt interest can be a tax deduction and set aside a greater operating profit for corporate investors. If operating income as a percentage of assets exceeds the interest rate on debt, the company can use debt to buy assets, pay interest on debt, and still get the remainder as a bonus for the company's shareholders (Brigham and Houston 2010: 141).
Besides funding through debt will force managers to be more disciplined, because if the debt is not paid in accordance with what is required by creditors, the company will go bankrupt, in which case the manager will lose his job (Brigham and Houston 2010: 185). While according to MM theory states that companies that have debt will have more value compared to companies without debt. This is because, an increase in the value of the company occurs because the payment of interest on debt is a tax deduction, therefore the operating profit received by investors will be greater, the next impact is because the profit received is greater, the value of the company will also be large (Kamaludin, 2011: 312). So the higher the capital structure that comes from debt, the higher the value of the company. So the hypotheses tested in this study are as follows:

\section{H1: Good Corporate Governance and capital structure influence firm value.}

The results of research on the effect of GCG on inconsistent corporate values indicate other factors that also interact. These results encourage researchers to include disclosure of Financial Performance as an interactive variable. Signal theory states that the company provides signals to outsiders with the aim of increasing the value of the company. In addition to the required financial information, the company also makes voluntary disclosures. Agency Theory discusses the relationship between principals (owners and shareholders) and agents. equity) to finance business activities.

This research uses the disclosure of financial performance as an intervening variable with the thought that the company's financial performance will provide a positive appreciation as indicated by the increase in achievement achieved by the company expressed as a percentage. 
This increase will cause the company's value to also increase. Miller and Modigliani (1961) stated that the value of a company is influenced by debt policy. Kim and Sorensen (1986) state that debt policy is influenced by capital structure. They stated that the value of the company is influenced by financial performance. Fuerst and Kang (2000) found a positive relationship between insider ownership and market value after controlling company performance. The value of a company can increase if the institution is able to be an effective monitoring tool. The relationship between analysts coverage which is an external monitoring function and Tobins'Q as a proxy for corporate value is positive and significant. Husnan (2000) states that financial performance is influenced by capital structure. Based on Miller and Modigliani (1961), Kim and Sorensen (1986), Fuerst and Kang (2000) we propose that there was a research gap that we should test and discuss, then the hypothesis that we built is :

$\mathrm{H} 2$ : there is an influence of Corporate Governance and capital structure on firm value through financial performance as an intervening variable.

\section{RESEARCH METHODS Population and Sample}

The population companies are all companies that have been listed on the Indonesia Stock Exchange in 2017-2018. While the sample selection using purposive sampling method with the type of judgment sampling is the selection of samples based on certain criteria (Cooper and Schindler, 2000). The sample selection criteria are as follows: (1) Manufacturing companies listed on the Indonesia Stock Exchange in 2017-2018, (2) Financial data of manufacturing companies in 2017-2018.

The object of this research is the manufacturing industry on basic and chemical sub-sector that listed in BEI in the years of 2017 to 2018 , the reason is because they have a good orientation on technological advance, have a good asset management as it is shown by the existence of a good Debt to Asset Ratio, and have a god prospect of market capital on stock trading. Dewata and Isnulhadi (2012) conclude Managerial ownership is the percentage of stock ownership by management that actively participates in corporate decision-making (directors and commissioners).

\section{Definition of Variables}

\section{Good Corporate Governance (GCG)}

Good Corporate Governance (GCG) uses a proxy Institutional ownership is the ownership of shares owned by institutional investors. Institutional investors include banks, pension funds, insurance companies, limited liability companies and other financial institutions. Institutional ownership is expressed as a percentage (\%) measured by comparing the number of shares owned by institutional investors Divided by the total number of shares outstanding. Based on Natalylova's research (2013: 171), to measure the ownership of outstanding institutional shares the following formula is used:

$\%$ institutional share $=\frac{\text { Number of institutional shares }}{\text { Number of shares outstanding }} \times 100 \%$

\section{Capital Structure}

Capital structure using the Debt to Assets Ratio proxy. Debt Ratio is one of the leverage ratios that shows how much the company's funding comes from the debt component. The amount of the Debt to Assets Ratio calculation results shows the total debt that can be guaranteed with total assets. The Debt to Assets Ratio shows the amount of funds provided by the creditor to the total assets owned by the company. With the higher portion of debt usage, the risk of the company will increase because debt creates a fixed interest expense on the company. The is 
Debt to Assets Ratio formulated as follows:

Debt to Assets Ratio $=\frac{\text { total amoun of debt }}{\text { total assets }}$

\section{Financial performance}

Company performance proxied by ROA is one of the profitability ratios that shows the company's ability to earn profits by optimizing the resources it has. ROA is a very important measure in evaluating the effectiveness and efficiency of company management in managing company assets. The higher ROA shows the better company performance. ROA is calculated by:

$$
\text { ROA }=\frac{\text { earning after tax }}{\text { Total Assets }}
$$

\section{The value of the company}

Company value is proxied by Tobin's $\mathrm{Q}$ value which is given the symbol $\mathrm{Q}$, calculated using the Tobin's $Q$ ratio with the following formula:

$$
\text { Tobin's } \mathbf{Q}=\frac{(\mathbf{E M V}+\mathbf{D})}{(\mathbf{E B V}+\mathbf{D})}
$$

Information:

$\mathrm{Q} \quad=$ the value of company

$\mathrm{EMV}=$ Equity Market Value $(\mathrm{EMV}=$ closing price $\mathrm{x}$ number of shares outstanding)

$\mathrm{D}=$ book value

$\mathrm{EBV}=$ Equity book of value

\section{Linear Regression}

Linear regression is a statistical tool used to determine the effect of one or several variables on a single variable. Variables that affect are often called independent variables, independent variables or explanatory variables. Variables that are affected are often called bound variables or dependent variables. Simple regression is based on functional or causal relationships of one independent variable with one dependent variable. While multiple linear regression is based on a linear relationship between two independent or more independent variables. The equation model is as follows:

$$
\begin{aligned}
& \mathrm{FV}=\beta 0+\beta 1 . \mathrm{GCG}+\beta 2 . \mathrm{CS} \ldots \ldots \ldots \ldots \ldots \\
& \mathrm{FP}=\beta 0+\beta 1 . \mathrm{GCG}+\beta 2 . \mathrm{CS} \ldots \ldots \ldots \ldots \ldots \\
& \mathrm{FV}=\beta 0+\beta 1 . \mathrm{FP} \ldots \ldots \ldots \ldots \ldots \ldots \ldots \ldots \\
& \mathrm{FV}=\beta 0+\beta 1 . \mathrm{GCG}+\beta 2 . \mathrm{CV}+\beta 3 . \mathrm{FP} \ldots
\end{aligned}
$$

\section{RESULT AND DISCUSSION}

\section{Data Description}

This study uses secondary data from companies listed on the Indonesia Stock Exchange (IDX), based on the results of the study obtained samples survived 2 years of the study period (2017-2018) with sampling techniques in this study using purposive sampling method. The sample companies used in this study are presented in Table 1.

\section{Descriptive statistics}

Descriptive statistics provide an initial description of the research variables and are used to determine the characteristics of the sample used in the study. In this study, descriptive statistics used include maximum, minimum, average and standard deviation (Ghozali, 2011). Descriptive statistics in this study are used to describe all the variables used in this study, namely good corporate governance, capital structure, company value and financial performance The descriptive statistics in this study are presented in Table 2.

Based on Table 2 for all samples totaling 79 companies for 2 years of observation, it can be seen that return on assets (ROA) which is a proxy for measuring the company's financial performance has an average of 0.1079 , the average sample company generates a profit of $10.79 \%$ of the total assets used, it can be seen that the sample company has an underperformance because it only produces an ROA ratio of $10.79 \%$ which 
means the company is only able to generate a profit of $10.79 \%$ of the total assets it has. The standard deviation value of $27.28 \%$ which is greater than the average value of ROA illustrates that the ROA variable data during the observation period has variation.

Measurement of capital structure is the ratio of Debt to Asset Ratio. With the higher portion of debt usage, the risk of the company will increase because debt creates a fixed interest expense on the company. The average value of the DER variable is $28.79 \%$ which indicates the average sample company on the Stock Exchange has a debt of $28.79 \%$ of the total equity that has been invested by shareholders. The next descriptive statistic is the TobinsQ variable which is a proxy of the company's value ratio EPS is used to see how much the value of the company compared to assets and debt. The positive value from the TobinsQ calculation reflects the company profit, and the negative value reflects the company being rug. Based on the average value of the TobinsQ 163.98 proxy, this shows that the average company has good corporate value.

The next statistical result is the mechanism of good corporate governance, namely the variable of the board of commissioners which is calculated by dividing the proportion of institutional commissioners $\mathrm{n}$ divided by the number of shares in stock. The average value of the INST variable is 0.437 , this explains that $43.7 \%$ of the total shares of the company are owned by institutional investors, which means the sample companies are not controlled by institutional investors (non controlling shareholders) so that the company's performance is considered to be poor.

\section{Classical Assumption Test}

Testing classic assumptions in this study include the normality test, the autocorrelation test, the multicollinearity test, and the heterokedasticity test. The classic assumption test in this study was carried out with the Statistical Package for the Social Sciences (SPPS) version 20 test tool.

\section{Normality test}

Normality test aims to test whether in the regression model, the two variables namely the independent variable and the dependent variable have a normal distribution or not (Ghozali, 2011). The results of normality testing for all variables are presented in Table 3.

\section{Autocorrelation Test}

Autocorrelation test is done to find out whether there is a correlation between the disturbance error in period $t$ and error in period t-1. Autocorrelation testing is done by looking at the $d$ value or the Durbin Watson coefficient (D-W). The autocorrelation test results are presented in Table 4.

\section{Multicollinearity Test}

Multicollinearity test was conducted with the aim to test whether the regression model found a correlation between the independent variables. To see the presence or absence of multicollinearity problems can be seen from the Tolerance and Variance Inflation Factor (VIF) values. The results of the multicollinearity test can be seen in Table 5 .

\section{Heteroscedasticity Test}

Heteroscedasticity testing aims to test whether in the regression model there is an inequality of variance from the residuals of one observation to another. If the correlation coefficient of all variables on residuals $>0.05$, it can be concluded that the regression model does not occur heteroscedasticity. Heteroscedasticity test results can be seen in Table 6 .

\section{First Hypothesis Testing}

Hypothesis testing in this study aims to see whether the form or implementation of good corporate governance and capital 
structure variables affect the firm's value with financial performance as an intervening variable. The result of hypotheses test presented in Table 7.

Based on Table 7, hypothesis test on the first model resulting a statistical Fvalue 181765.107 and significance level below $0,05(\mathrm{p}=0.000)$, it is indicate that the model is fit and the variables of Corporate Governance and Capital Structure simultaneously and significantly affect the variable value of the company which is measured using the Tobinsq ratio. The adjusted R2 value of 1.00 indicates that all independent variables explain the dependent variable.

\section{Second Hypothesis Testing}

The second hypothesis testing in this study is to measure whether the appearance or implementation of good corporate governance and capital structure variables affect the firm's value with financial performance as an intervening variable. To test the second hypotheses, we measure three equation on the reseach models.

Based on Table 8, testing the hypothesis for the fourth model obtained a statistical $F$ value of 174236.842 and a significance level of $0.00<0.05$, it can be concluded that the model is fit and the variables of Corporate Governance, Capital Structure and Financial performance simultaneously and significantly affect company value variables measured using the Tobinsq ratio. The adjusted $\mathrm{R} 2$ value of 1.207 indicates that all independent variables explain the dependent variable.

Tabel 1. Number of Secondary Data

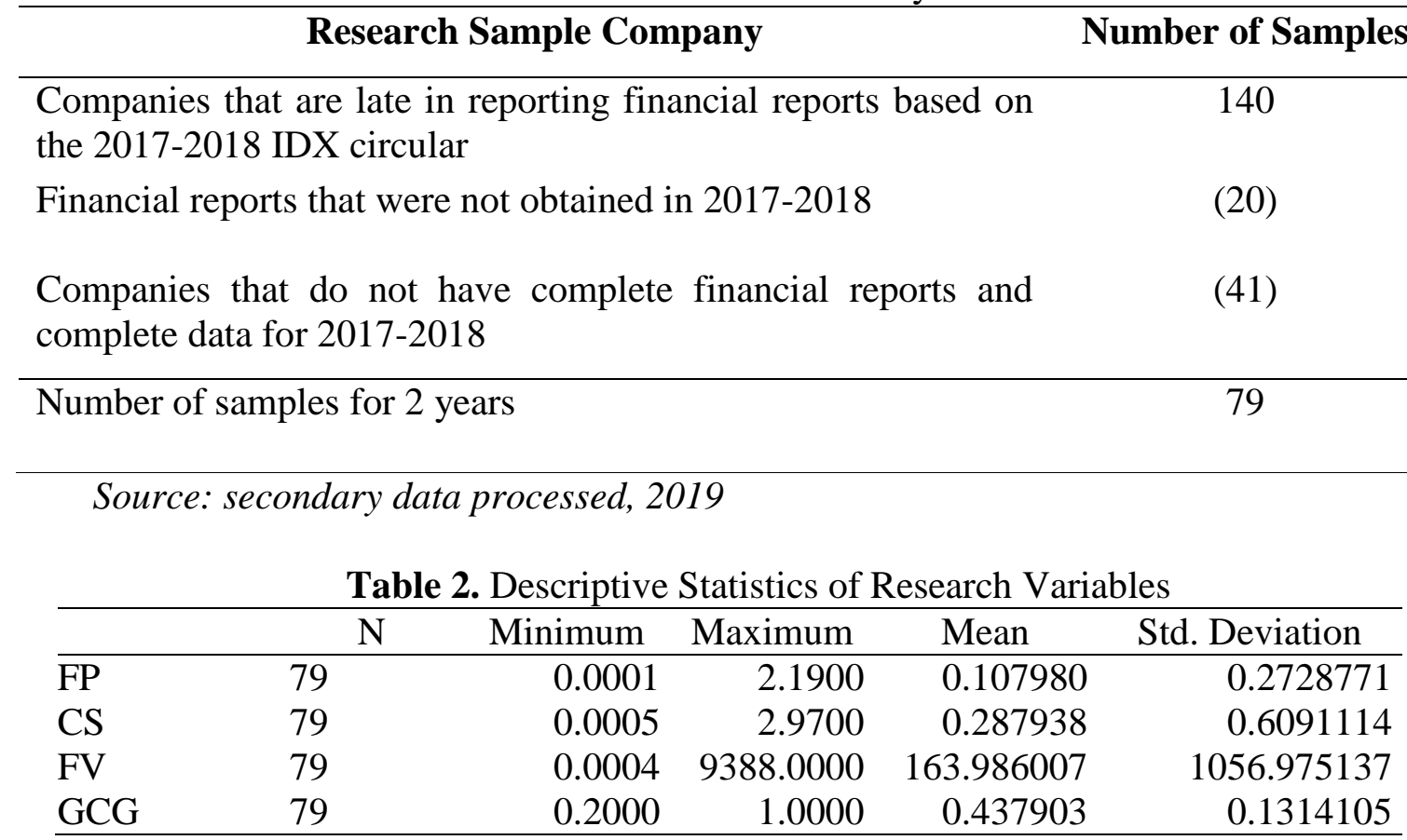

Source: secondary data processed, 2019 
Table 3. Test of Normality

\begin{tabular}{ll}
\hline Equation 1 & \\
Kolmogorov-Smirnov Z & 0.547 \\
Asymp. Sig. (2-tailed) & 0.926 \\
Description & Normal Data \\
\hline Equation 2 & \\
Kolmogorov-Smirnov Z & 0.663 \\
Asymp. Sig. (2-tailed) & 0.772 \\
Description & Normal Data \\
\hline Equation 3 & \\
Kolmogorov-Smirnov Z & 0.674 \\
Asymp. Sig. (2-tailed) & 0.754 \\
Description & Normal Data \\
\hline Equation 4 & \\
Kolmogorov-Smirnov Z & 0.557 \\
Asymp. Sig. (2-tailed) & 0.916 \\
Description & Normal Data \\
\hline
\end{tabular}

Source: secondary data processed, 2019

Table 4. Autocorrelation Test Results

\begin{tabular}{|c|c|c|c|c|c|}
\hline \multicolumn{6}{|c|}{ Equation 1} \\
\hline $\mathrm{K}$ & DL & DU & DW & CRITERIA & DESCRIPTION \\
\hline 2 & 1,4402 & 1,6785 & 1,893 & $1,6785<\mathrm{DW}<2,315$ & Autocorrelation Free \\
\hline \multicolumn{6}{|c|}{ Equation 2} \\
\hline $\mathrm{K}$ & DL & DU & DW & CRITERIA & DESCRIPTION \\
\hline 2 & 1,4797 & 1,6785 & 2,037 & $1,6785<\mathrm{DW}<2,315$ & Autocorrelation Free \\
\hline \multicolumn{6}{|c|}{ Equation 3} \\
\hline $\mathrm{K}$ & DL & DU & DW & CRITERIA & DESCRIPTION \\
\hline 3 & 1,448 & 1,831 & 1,939 & $1,6785<$ DW $<2,315$ & Autocorrelation Free \\
\hline \multicolumn{6}{|c|}{ Equation 4} \\
\hline $\mathrm{K}$ & DL & DU & DW & CRITERIA & DESCRIPTION \\
\hline 3 & 1,448 & 1,831 & 2,084 & $1,6785<\mathrm{DW}<2,315$ & Autocorrelation Free \\
\hline
\end{tabular}

Table 5. Multicollinearity Test Results

\begin{tabular}{llll}
\hline Equation 1 & Tolerance & VIF & Description \\
Variable & 0.333 & 3.005 & Multicollinearity free \\
FV & 0.337 & 2.970 & Multicollinearity free \\
GCG & 0.974 & 1.028 & Multicollinearity free \\
CS & & & \\
\hline Equation 2 & 0.858 & 1.166 & Multicollinearity free \\
FV & 0.964 & 1.037 & Multicollinearity free \\
GCG & 0.664 & 1.506 & Multicollinearity free \\
CS & & & \\
\hline Equation 3 & 0.859 & 1.165 & Multicollinearity free \\
FV & 0.803 & 1.245 & Multicollinearity free \\
FP & & & \\
Equation 4 & 0.643 & 1.554 & Multicollinearity free \\
FV & 0.894 & 1.119 & Multicollinearity free \\
GCG & 0.633 & 1.579 & Multicollinearity free \\
CS & 0.877 & 1.140 & Multicollinearity free \\
FP & & & \\
\hline
\end{tabular}


Table 6. Heteroscedasticity Test Results

\begin{tabular}{llll}
\hline Equation 1 & & & \\
Variable & Tolerance & Significant & Description \\
FV & 0.297 & 0.767 & Heteroscedasticity free \\
GCG & 1.264 & 0.211 & Heteroscedasticity free \\
CS & -0.088 & 0.930 & Heteroscedasticity free \\
\hline Equation 2 & & & \\
FP & 1.520 & 0.133 & Heteroscedasticity free \\
GCG & 1.910 & 0.061 & Heteroscedasticity free \\
CS & 1.293 & 0.201 & Heteroscedasticity free \\
\hline Equation 3 & & & \\
FV & -1.022 & 0.311 & Heteroscedasticity free \\
FP & -0.112 & 0.911 & Heteroscedasticity free \\
\hline Equation 4 & & & \\
FV & 1.976 & 0.052 & Heteroscedasticity free \\
GCG & -0.071 & 0.944 & Heteroscedasticity free \\
CS & 1.242 & 0.219 & Heteroscedasticity free \\
FP & -0.056 & 0.955 & Heteroscedasticity free \\
\hline Source: secondery
\end{tabular}

Source: secondary data processed, 2019

Table 7. First Hypothesis Testing

\begin{tabular}{llll}
\hline \multicolumn{4}{c}{ Equation 1} \\
Koef & T & Sig \\
\hline GCG & 0.029 & 1.726 & 0.000 \\
CS & -0.005 & 0.594 & 0.000 \\
\hline Adjusted $\mathrm{R}^{2}$ & \multicolumn{3}{c}{1.000} \\
F & \multicolumn{3}{c}{181765.107} \\
\hline Source: secondary data processed 2019
\end{tabular}

Source: secondary data processed, 2019

Table 8. Second Hypothesis Testing

\begin{tabular}{|c|c|c|c|c|c|c|c|c|c|}
\hline & \multicolumn{3}{|l|}{ Equation 2} & \multicolumn{3}{|c|}{ Equation 3} & \multicolumn{3}{|c|}{ Equation 4} \\
\hline & Koef & $\mathrm{T}$ & Sig & Koef & $\mathrm{T}$ & Sig & Koef & $\mathrm{T}$ & Sig \\
\hline$\overline{\text { GCG }}$ & 239.13 & 1.56 & 0.00 & & & & 98.635 & 0.367 & 0.00 \\
\hline $\mathrm{CS}$ & 5115.12 & 0.42 & 0.00 & & & & 602.68 & 1.729 & 0.00 \\
\hline FP & & & & 670.08 & 0.594 & 0.00 & 284.14 & 0.291 & 0.00 \\
\hline $\mathrm{F}$ & & & & & & & 174236.8 & & \\
\hline $\mathrm{R}^{2}$ & & & & & & & 1.207 & & \\
\hline
\end{tabular}

Source: secondary data processed, 2019

\section{DISCUSSION}

\section{Effect of Corporate Governance and Capital Structure on firm value}

Corporate Governance variable measured by institutional ownership and capital structure measured by debt to asset ratio has a positive regression coefficient to the value of the company with a significance level of 0.00 less than 0.05 . That is, institutional ownership and capital structure are significantly proven to affect the value of the company. The existence of ownership by institutional investors will encourage increased oversight of more optimal management performance, because ownership of shares represents a source of power that can be used to support or vice 
versa on management performance (Kusumaningtyas, 2015). Institutional share ownership has a positive effect indicating that the control function of the owner is crucial in improving company performance. Theoretically, the higher institutional ownership, the stronger control over the company, the performance / value of the company will increase if the owner of the company can control management behavior to act in accordance with company goals (Widyati, 2013). The greater the institutional ownership, the more efficient the use of company assets and it is also expected to act as a prevention against waste by the management. The greater the ownership by financial institutions, the greater the sound power and drive to optimize corporate value (Suhartanti, 2015). So the higher the institutional ownership, the higher the value of the company.

An increase in firm value will be caused by additional debt as long as the capital structure is below its optimal point, this is explained by the Trade-off Theory where the benefits from increased debt are still greater than expenses, the benefits of additional debt are influences directly on the firm's value. The increase in the firm value due to an increase in the amount of debt (debt is still below the optimal point) is caused by the management of the company that uses the debt for business expansion of the company.

\section{The Effect of Corporate Governance and Capital Structure on Company Value with Financial Performance as an intervening variable}

The measurement of Corporate Governance and Capital Structure of Firm Value with Financial Performance as an intervening variable has a positive regression coefficient on firm value with a significance level of 0.00 less than 0.05 . That is, institutional ownership and capital structure on Firm Value with Financial
Performance as an intervening variable is significantly proven to affect the firm's value.

Based on the signaling theory, the company provides signals to outside parties with the aim of increasing the value of the company. In addition to the required financial information, the company also makes voluntary disclosures. Agency Theory discusses the relationship between principals (owners and shareholders) and agents. equity) to finance business activities. This research uses the disclosure of financial performance as an intervening variable with the thought that the company's financial performance will provide a positive appreciation as indicated by the increase in achievement achieved by the company expressed as a percentage. This increase will cause the company's value to also increase. Miller and Modigliani (1961) stated that the value of a company is influenced by debt policy. Kim and Sorensen (1986) state that debt policy is influenced by capital structure. They stated that the value of the company is influenced by financial performance. Fuerst and Kang (2000) found a positive relationship between insider ownership and market value after controlling company performance. Company value can increase if the institution is able to be an effective monitoring tool. The relationship between analysts coverage which is an external monitoring function and Tobins'Q as a proxy for corporate value is positive and significant.

\section{CONCLUSION}

Based on the result of our research we conclude that corporate governance and capital structure influence the value of the company by using the ratio of institutional ownership and capital structure. This means that institutional ownership owned by the institution and efficient use of capital can increase the value of the firm. The result shows that the impact of 
Corporate governance and capital structure to firm value are mediated by financial performance. This means the value of the firm can increase if the company able became an effective monitoring tool. The impact of analysts coverage which is an external monitoring function and Tobins'Q as a proxy for corporate value is positive and significant.

\section{Research Limitations}

This research is inseparable from the company ampel is limited to 79 sample companies that can only be used for research, because almost half the other data do not meet the sample criteria.

\section{REFERENCES}

Atidhira, A. T., \& Yustina, A. I. (2017). The Influence of Return on Assets, Debt to Equity Ratio, Earnings per Share, and Company Size on Share Return in Property and Real Estate Companies. JAAF (Journal of Applied Accounting and Finance), 1(2), 128-146.

Brigham, E. F. \& Houston. (2011). Dasardasar Manajemen Keuangan, Edisi Sebelas, Alih Bahasa Ali Akbar Yulianto. Jakarta: Penerbit Salemba Empat.

Effendi, M.B (2017). Financial Performance in Manufacturing Company with Multiple Linier Regression and MARS. Jurnal Keuangan dan Perbankan, 22(1), 103-113.

Forum for Corporate Governancein Indonesia. (2002). Peranan Dewan Komisaris danKomite Audit dalam Pelaksanaan Corporate Governance (Tata Kelola Perusahaan). www.fcgi.or.id, 2002. (10 Januari 2016).
Garbo, A., \& Wulandari, D. A. (2018). The Implementation of Good Corporate Governance In The Aerofood Acs Company Of Yogyakarta. Journal of Islamic Economics. Lariba, 4(1), 4756.

Ghozali, I. (2011). Analisis Multivariate dengan program IBM SPSS 19. Semarang: Badan Penerbit Fakultas Ekonomi Universitas Diponegoro.

Healy, P. M., \& Wahlen, J. M. (1999). A review of the earnings management literature and its implications for standard setting. Accounting Horizons, 13(4), 365-383.

Husnan, S., \& E. Pudjiastuti, E. (2004). Dasar-dasar Manajemen Keuangan, Edisi Keempat. Yogyakarta: UUP AMP YKPN, Yogyakarta.

Kanter, A. B., \& Siagian, J. (2017). Pengaruh Kinerja Keuangan terhadap Return Saham. Fundamental management journal, 2(2), 17-26.

Merchant, K. A., \& Rockness, J. (1994). The ethics of managing earnings: An empirical investigation. Journal of Accounting and Public policy, 13(1), 79-94. 